\title{
PREDICTION SULPHURIC ACID AND WATER VAPOUR DEW POINT TEMPERATURES OF FLUE GASES AND COMBUSTION ANALYSIS FOR SOLID FUELS IN TURKEY
}

\author{
Meryem Terhan ${ }^{1, *}$
}

\begin{abstract}
In the study, the combustion analysis is examined for the solid fuels in Turkey. The principal aim of the analysis is determined the limits and obstacles in the design heat exchanger to avoid the corrosion risk on the heat exchanger surfaces in the latent heat recovery applications from waste flue gas. To do this, in which regions of the heat exchanger the flue gas temperature reached to the sulphuric acid and water vapour dew point temperatures are required to predict. In order to predict the condensing zone, an air preheater for the coal-fired boiler in a heating system is designed using finite difference method. Designed the air preheater is consists of the counter-cross flow, Ushaped stainless steel tube bundle. The tube is discredited 200 cells to one-dimensional during the flow. The heat transfer rates, the flue gas and air inlet and outlet temperatures, surface temperatures of the tube wall, the mole fractions of water and sulphuric acid vapour, the other non-condensing gases in the flue gas are calculated in each discrete cell. According to the results of the study, while the dew point temperature of the water vapour changes over the range $30-40{ }^{\circ} \mathrm{C}$, the acid dew point temperature waves to $125^{\circ} \mathrm{C}$ from $140{ }^{\circ} \mathrm{C}$ for the coal types mined in Turkey.
\end{abstract}

\section{Keywords: Solid Fuels, Combustion Analysis, Acid Dew Point Temperature, Heat Recovery from Flue Gas, Air Preheater}

\section{INTRODUCTION}

The solid fuels contain sulphur, nitrogen and carbon and hydrogen. In the result of fuel combustion in the boiler, the flue gas consists of $\mathrm{H}_{2} \mathrm{O}, \mathrm{O}_{2}, \mathrm{CO}_{2}, \mathrm{~N}_{2}, \mathrm{SO}_{2}$ and $\mathrm{SO}_{3}$. In the heat recovery applications from flue gas, the sulphur dioxide reacts with the water vapour and, sulphuric acid vapour $\left(\mathrm{H}_{2} \mathrm{SO}_{4}\right)$ emerges. When water and sulphuric acid vapours in the flue gas are contacted cold surfaces in the heat exchanger, these vapours condense under dew point temperatures. As the condensed solution is further acidic, low-temperature corrosion effects appear on heat exchanger surfaces [1-2]. Thus, predicting the dew point temperatures of the water vapour and sulfuric acid is very important in the design of latent heat recovery units. In the design calculations of the latent heat recovery units for boiler must be examined in detail three important issues. These issues can be classified as the sulphur content of the fuel, excess air ratio and the temperature of the inlet feed water [3].

In the ratio of $1-5 \%$, a small part of $\mathrm{SO}_{2}$ in flue gas transforms into $\mathrm{SO}_{3}$. If flue gas temperature is lower than $176{ }^{\circ} \mathrm{C}$, the whole of $\mathrm{SO}_{3}$ converts into $\mathrm{H}_{2} \mathrm{SO}_{4}$. Even if the lower existence of 5-50 ppm, the amount of sulphuric acid vapour in flue gas is the most important for acid dew point [1].

When the flue gas temperature is reached their dew points, the condensation of water and sulphuric acid vapour occurs on tube bundles inside the heat exchanger. The dew point of sulphuric acid is higher than water vapour's dew point. Thus, the sulphuric acid vapour in flue gas is firstly condensed. As the flue gas temperature is reduced lower than this point, the condensation of water vapour starts. In the design calculations of the latent heat exchanger, the outside wall temperature of tubes should be calculated each meter length in order to predict the area capable of condensation. If the outside wall temperature of the tube inside the heat exchanger reaches the dew point, the condensation begins there. The condensation causes high speed of corrosion over the exposed area of the heat exchanger tube bundles, which could represent a serious risk of breakdown. For this reason, predicting of dew points is more important for the industrial fields [4]. The waste heat exchanger has played an important role in the industrial process such as chemical, petroleum, medicine and power plants to recover the waste heat from flue gas and save 
fuel and money. The corrosions, emerge on the heat exchanger tubes can be classified as high-temperature corrosion, stress corrosion cracking and dew point corrosion or low-temperature corrosion [5-6].

Han et al. [7] developed a new numerical model to predict the condensation rate of sulphuric acid and condensate acidic solution concentration on the heat exchanger surfaces. According to the results of the study, increasing the flue gas temperature is reduced the corrosion risk by reducing the condensation rate and acid concentration. Vainio et al. [8] conducted a study about low-temperature corrosion in co-combustion of biomass and solid recovered fuels. The cause of low-temperature corrosion was studied in a full-scale boiler firing bank. According to the study, the risk of sulphuric acid dew point corrosion is minimum during combustion of biomass with a low sulphur content ( $0.3 \mathrm{ppm})$, and when the moisture concentration in the flue gas was lower (17-18 vol.\%.), no corrosion could be observed. Wei et al. [1] studied the theoretical prediction of acid dew point and safe operating temperature of heat exchangers for coal-fired power plants. They examined the impacts of temperature, acid vapour content and water vapour content on the acid solution concentration and condensation rate. As a result of the study, the lowest temperature of the heat exchanger was recommended above $80^{\circ} \mathrm{C}$ in the practical application of waste heat recovery in coal-fired boilers considering the low-temperature corrosion. Zarenezhad and Aminian [9] presented a new approach based on using an artificial neural network model to predict the acid dew points. The LevenbergMarquardt backpropagation algorithm was used for network training. They inferred that the acid dew point is very sensitive to the flue gas $\mathrm{SO}_{3}$ concentration such that a small increase in $\mathrm{SO}_{3}$ concentration leads to a significant increase in sulphuric acid dew point at a given $\mathrm{H}_{2} \mathrm{O}$ concentration.

Ding et al. [5] analyzed the dew point corrosion on economizer tubes of a waste heat boiler for a company in their study. The necessary of a desulfurizer for the boiler to eliminate the sulphuric acid dew point, monitoring and controlling of sulphur content in flue gas, raising the temperature of flue gas to avoid the dew point corrosion, taking control of the moisture in flue gas and renovating the heavily corroded heat exchanger tubes with 304 stainless steel tubes were recommended the company. Pena and Blanco [4] a new methodology to predict the physical dew point inside an economizer depending on fuel type burned were developed in their study. Only physical dew point (water vapour's dew point) was taken into account. Acid dew point (sulphuric acid vapour's dew point) has not been considered because of natural gas used as fuel. The natural gas has almost undetectable sulphur contents. As a result of the study, the first $3 \mathrm{~m}$ of the tube bundle was clearly exposed to fast corrosion because the temperatures in contact with the outside wall of the tube bundle were lower than the dew point temperature calculated there. Besides, as the excess air ratio decreases in the combustion process, the physical dew point temperature increases inside the heat exchanger. Li et al. [10] suggested an updated formula for determining acid dew point temperature of flue gas. The formula was validated with various data obtained the experiments and industrial coal-fired power plants of air and oxy-fuel combustion and also compared to the conventional empirical formulas to confirm its accuracy. In this study, they proved the accuracy much higher than the conventional empirical formula for the air-firing combustion process. Shi et al. [11] conducted the experimental study to investigate the corrosion of the tube heat transfer surface under the ultra-low tube wall temperature circumstance for a waste heat recovery system in the coal-fired boilers. They observed two tuning zones, the first one emerges when the wall temperature is about $32-36{ }^{\circ} \mathrm{C}$ lower than the acid dew point, and the second one is about $10{ }^{\circ} \mathrm{C}$ higher than the water vapour dew point. Xiang et al. [2] presented the study of the prediction model on the acid dew point temperature in previous studies. By investigating the previous models on the acid dew point prediction, a formula was derived, and a semi-empirical prediction model was proposed in their study.

Blanco and Pena [3] conducted a study about predicting the acid dew point temperature of the baskets on rotating regenerative air pre-heaters by using data obtained in a power plant. In their study, they examined the acid dew point temperature for the two fuel type, called Fuel No: 2 and low sulphur fuel. Experimental values obtained for the power plant was very close to the theoretical values given in this study.

In this study, the combustion analysis is investigated for solid fuels such as various coal and wood types with moist air for different cities in Turkey. For the fuel types, the combustion effects are examined by using different excess air ratio. The dew point temperatures of water vapour (WDT) and sulphuric acid (ADT) are predicted as theoretical for various solid fuels types and the different cities in Turkey. The various factors such as the excess air ratio, relative humidity rate and the altitude of the city affected to the dew point temperatures and the 
concentration of the water and sulphuric acid vapour in flue gases are studied. In order to predict the condensing, an air pre-heater for the coal-fired boiler is designed using finite difference method. The tube is discredited 200 cells to one-dimensional during the flow. The heat transfer rates, the flue gas and air inlet and outlet temperatures, surface temperatures of the tube wall, the mole fractions of water vapour, sulphuric acid vapour and other non-condensing gases in the flue gas are calculated in each discrete cell.

\section{THEORETICAL ANALYSIS}

For combustion analysis of the boilers in the system, the following assumptions are done:

- The mass and energy balances equations at steady state for the material flow in the boiler are obtained with negligible potential and kinetic energy changes.

- The flue gases outside from the boiler are assumed to be ideal gases.

- In the combustion analysis, the reaction of the combustion in the boilers is complete combustion with moist air.

\section{Combustion Analysis of Moist Coal as Fuel in a Boiler}

Coal consists of hydrocarbons, sulphur, oxygen, nitrogen, moisture and ash. The stoichiometric combustion reaction of the moist coal with dry air in the boiler's combustor is stated as:

$$
\begin{aligned}
& C_{x} H_{y} \mathrm{O}_{z} \mathrm{~N}_{t} S_{m}\left(\mathrm{H}_{2} \mathrm{O}\right)_{n}+\mathrm{a}\left(\mathrm{O}_{2}+3.76 N_{2}\right) \\
& \rightarrow x \mathrm{CO}_{2}+\left(\frac{y}{2}+n\right) \mathrm{H}_{2} \mathrm{O}+\mathrm{mSO}_{2}+\left(\frac{t}{2}+3.76 \times a\right) N_{2} \\
& a=x+\frac{y}{4}-\frac{n}{2}+m-z \\
& x=\frac{C \%}{100 \times M_{A-C}}(\mathrm{kmol} / \mathrm{kg} \text { fuel }) \\
& y=\frac{H \%}{100 \times M_{A-H}}(\mathrm{kmol} / \mathrm{kg} \text { fuel }) \\
& z=\frac{O \%}{100 \times M_{A-O}}(\mathrm{kmol} / \mathrm{kg} \mathrm{fuel}) \\
& t=\frac{N \%}{100 \times M_{A-N}}(\mathrm{kmol} / \mathrm{kg} \text { fuel }) \\
& m=\frac{S \%}{100 \times M_{A-S}}(\mathrm{kmol} / \mathrm{kg} \text { fuel }) \\
& n=\frac{\left(\mathrm{H}_{2} \mathrm{O} \%\right.}{100 \times M_{A-\mathrm{H}_{2} \mathrm{O}}}\left(\frac{\mathrm{kmol}}{\mathrm{kg}} \mathrm{fuel}\right)
\end{aligned}
$$

In the above formulas, $\mathrm{M}_{\mathrm{A}}$ is shown the molecular mass of carbon, hydrogen, nitrogen, oxygen, sulphur and moisture in the coal. The complete combustion reaction with moist air is given as: 
Journal of Thermal Engineering, Research Article, Vol. 7, No. 2, Special Issue 13, pp. 30-46, February, 2021

$$
\begin{aligned}
& C_{x} H_{y} \mathrm{O}_{z} \mathrm{~N}_{t} S_{m}\left(\mathrm{H}_{2} \mathrm{O}\right)_{n}+\lambda \mathrm{a}\left[\mathrm{O}_{2}+3.76 N_{2}+\varepsilon\left(\mathrm{H}_{2} \mathrm{O}\right)\right] \\
& \rightarrow x \mathrm{CO}_{2}+\frac{y}{2} \mathrm{H}_{2} \mathrm{O}+m S O_{2}+\left(\frac{t}{2}+3.76 \lambda a\right) N_{2}+\alpha O_{2}
\end{aligned}
$$

In Eq. (9), $\lambda$ is the excess air ratio. As the flue gases (products) are assumed to be ideal gases, $\varepsilon$ and $\alpha$ are calculated as [12]:

$$
\begin{gathered}
\alpha=\frac{z}{2}+\frac{n}{2}+\lambda \cdot a+\left(\frac{\lambda \cdot a \cdot \varepsilon}{2}\right)-x-\frac{y}{4}-m \\
\varepsilon=N_{m, \text { air }}=\frac{P_{m, \text { air }}}{P_{\text {atm }}} \times N_{f g}
\end{gathered}
$$

In Eq. (10) and (11), $\varepsilon$ is the mole number of moisture in the air. $\mathrm{N}_{\mathrm{fg}}$ (the mole number of flue gases) can be calculated the complete combustion reaction in Eq. (9).

$$
\begin{gathered}
N_{f g}=x+\frac{y}{2}+m+\left(\frac{t}{2}+3.76 \cdot \lambda \cdot a\right)+\alpha \\
P_{\text {total,air }}=\phi_{\text {air }} \times P_{\text {sat }}
\end{gathered}
$$

To find the pressure of the moist air, the relative humidity rate and the saturated pressure at the temperature of the air are required.

\section{Combustion Analysis of Wood as Fuel}

Wood consists of hydrocarbons, oxygen, nitrogen, moisture, ash and no sulphur. The complete combustion reaction with moist air is given as:

$$
\begin{array}{r}
C_{x} H_{y} \mathrm{O}_{z} \mathrm{~N}_{t}\left(\mathrm{H}_{2} \mathrm{O}\right)_{n}+\lambda \mathrm{a}\left[\mathrm{O}_{2}+3.76 N_{2}+\varepsilon\left(\mathrm{H}_{2} \mathrm{O}\right)\right] \\
\rightarrow x C \mathrm{O}_{2}+\frac{y}{2} \mathrm{H}_{2} \mathrm{O}+\left(\frac{t}{2}+3.76 \lambda a\right) N_{2}+\alpha O_{2} \\
\alpha=\frac{z}{2}+\frac{n}{2}+\lambda \cdot a+\left(\frac{\lambda \cdot a \cdot \varepsilon}{2}\right)-x-\frac{y}{4} \\
N_{f g}=x+\frac{y}{2}+\left(\frac{t}{2}+3.76 \cdot \lambda \cdot a\right)+\alpha
\end{array}
$$

\section{Sulphuric and Water Vapour Dew Point Temperatures}

As the flue gases (products) are assumed to be ideal gases, the partial pressure of the water vapour in the flue gases and the dew point temperature of water vapour can be calculated by using following equations [12].

$$
P_{H_{2} O}=\frac{N_{H_{2 O}}}{N_{f g}} \times P_{a t m}
$$


Journal of Thermal Engineering, Research Article, Vol. 7, No. 2, Special Issue 13, pp. 30-46, February, 2021

$T_{W D P}=0.001173333 \times\left(P_{H_{2} O}\right)^{3}-0.0942 \times\left(P_{H_{2} O}\right)^{2}+3.429666667 \times\left(P_{H_{2} O}\right)+19.7(18$

In the ratio of $1-5 \%$, a small part of $\mathrm{SO}_{2}$ in flue gas transforms into $\mathrm{SO}_{3}$. If flue gas temperature is lower than $176{ }^{\circ} \mathrm{C}$, the whole of $\mathrm{SO}_{3}$ converts into $\mathrm{H}_{2} \mathrm{SO}_{4}$. To determine the acid dew point temperature Okkes-B's equation, shown in Equation 20 is used [2].

$$
\begin{gathered}
\mathrm{SO}_{2}+1 / 2 \mathrm{O}_{2} \rightarrow \mathrm{SO}_{3} \\
T_{A D P}=203.25+27.6 \times \lg P_{\mathrm{H}_{2} \mathrm{O}}+10.83 \times \lg P_{\mathrm{SO}_{3}}+1.06 \times\left(\lg P_{\mathrm{SO}_{3}}+8\right)^{2.19}
\end{gathered}
$$

In Equation 20 given the formula, the pressure unit is atm. Because of the no content sulphur in wood, the sulphuric acid vapour doesn’t occur.

\section{RESULTS AND DISCUSSION}

The combustion reaction of the coal mined from Zonguldak in Turkey is indicated in Equation 21. In the equation, the stoichiometric combustion reaction occurs with dry air.

$$
\begin{aligned}
& C_{0.5948} H_{0.3611} \mathrm{O}_{0.0244} \mathrm{~N}_{0.0068} S_{0.0024}\left(\mathrm{H}_{2} \mathrm{O}\right)_{0.0106}+0.6753\left(\mathrm{O}_{2}+3.76 N_{2}\right) \\
& \quad \rightarrow 0.5948 \mathrm{CO}_{2}+0.1911 \mathrm{H}_{2} \mathrm{O}+2.5424 N_{2}+0.0024 \mathrm{SO}_{2}
\end{aligned}
$$

According to the types, the mass compositions of coal mined from some regions in Turkey are shown in Table $1[13]$.

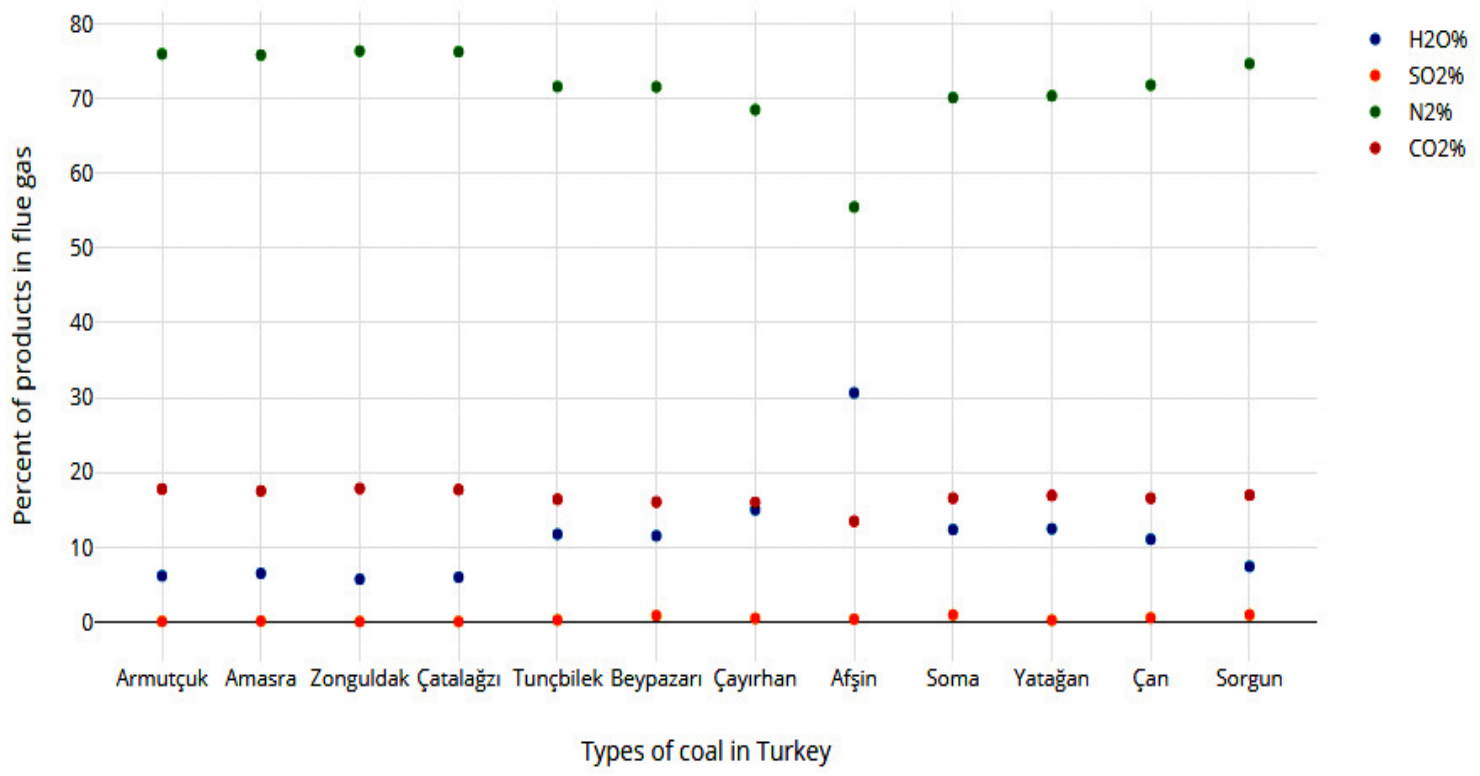

Figure 1. Percent of stoichiometric combustion products with dry air for the coal types 
Journal of Thermal Engineering, Research Article, Vol. 7, No. 2, Special Issue 13, pp. 30-46, February, 2021

Table 1. The chemical composition of some coals in Turkey

\begin{tabular}{|c|c|c|c|c|c|c|c|}
\hline Region & Type & $\mathrm{C} \%$ & $\mathrm{H} \%$ & $\mathrm{O} \%$ & N\% & $\mathrm{S} \%$ & Moisture \% \\
\hline Armutçuk & \multirow{4}{*}{ 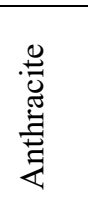 } & 82.80 & 4.52 & 7.94 & 1.32 & 0.99 & 2.43 \\
\hline Amasra & & 81.61 & 4.66 & 7.10 & 1.40 & 1.75 & 3.49 \\
\hline Zonguldak & & 86.52 & 4.38 & 4.72 & 1.15 & 0.92 & 2.30 \\
\hline Çatalağzı & & 86.31 & 4.60 & 4.60 & 1.15 & 0.92 & 2.42 \\
\hline Tunçbilek & \multirow{8}{*}{ 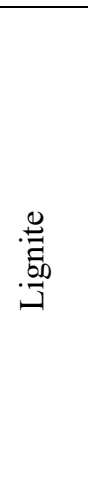 } & 56.05 & 4.25 & 13.20 & 2.07 & 2.51 & 21.92 \\
\hline Beypazarı & & 52.06 & 4.38 & 17.53 & 1.80 & 7.60 & 16.62 \\
\hline Çayırhan & & 44.71 & 3.49 & 15.38 & 1.08 & 3.73 & 31.61 \\
\hline Afşsin & & 22.67 & 2.42 & 16.00 & 1.82 & 1.70 & 55.39 \\
\hline Soma & & 46.48 & 3.94 & 23.89 & 2.03 & 7.17 & 16.49 \\
\hline Yatağan & & 50.93 & 4.19 & 21.98 & 2.21 & 2.09 & 18.60 \\
\hline Çan & & 55.14 & 4.22 & 16.86 & 1.41 & 5.08 & 17.30 \\
\hline Sorgun & & 64.73 & 3.83 & 11.60 & 1.86 & 9.86 & 8.12 \\
\hline
\end{tabular}

In the combustion analysis, the values shown in Table 1 of the mass compositions were used. The combustion analysis was firstly done according to dry air and then developed for the moist air of the various cities. The percent of combustion products with dry air are shown in Figure 1 for the types of coal mined from Turkey. In the combustion with the moisture air, the mole number of the moisture air changes with the relative humidity rate. In Table 2, the average relative humidity rates, the altitudes from sea level and the atmospheric pressures of the various cities in Turkey are given.

Table 2. The physical properties of cities used in the analysis

\begin{tabular}{|c|c|c|c|c|c|}
\hline City & Trabzon & Bursa & Ankara & Kayseri & Kars \\
\hline R. humidity\% & 69.41 & 70.34 & 59.95 & 61.62 & 73.48 \\
\hline Altitude (m) & 0 & 201 & 938 & 1054 & 1768 \\
\hline $\begin{array}{c}\text { Atmospheric } \\
\text { Pressure (kPa) }\end{array}$ & 101.325 & 98.93 & 90.56 & 89.29 & 81.81 \\
\hline
\end{tabular}

For the city, Ankara has the percent of average relative humidity 59.95 in Turkey; the complete combustion reaction is given the Eq. (22) according to the coal type mined from Zonguldak region. In the equation, the excess air ratio $(\lambda)$ is taken as 1.3. When the excess air ratio is increased, the percent of the $\mathrm{O}_{2}$ and $\mathrm{N}_{2}$ rise, however, the percent of the $\mathrm{CO}_{2}, \mathrm{H}_{2} \mathrm{O}$ and the $\mathrm{SO}_{2}$ decrease in the flue gas. The effect mentioned is given in Tab.3.

$$
\begin{gathered}
C_{0.5948} H_{0.3611} \mathrm{O}_{0.0244} \mathrm{~N}_{0.0068} S_{0.0024}\left(\mathrm{H}_{2} \mathrm{O}\right)_{0.0106}+1.13 \times 0.6753\left(\mathrm{O}_{2}+3.76 \mathrm{~N}_{2}\right) \\
\rightarrow 0.5948 \mathrm{CO}_{2}+0.2569 \mathrm{H}_{2} \mathrm{O}+3.3041 \mathrm{~N}_{2}+0.0024 \mathrm{SO}_{2}+0.2026 \mathrm{O}_{2}
\end{gathered}
$$




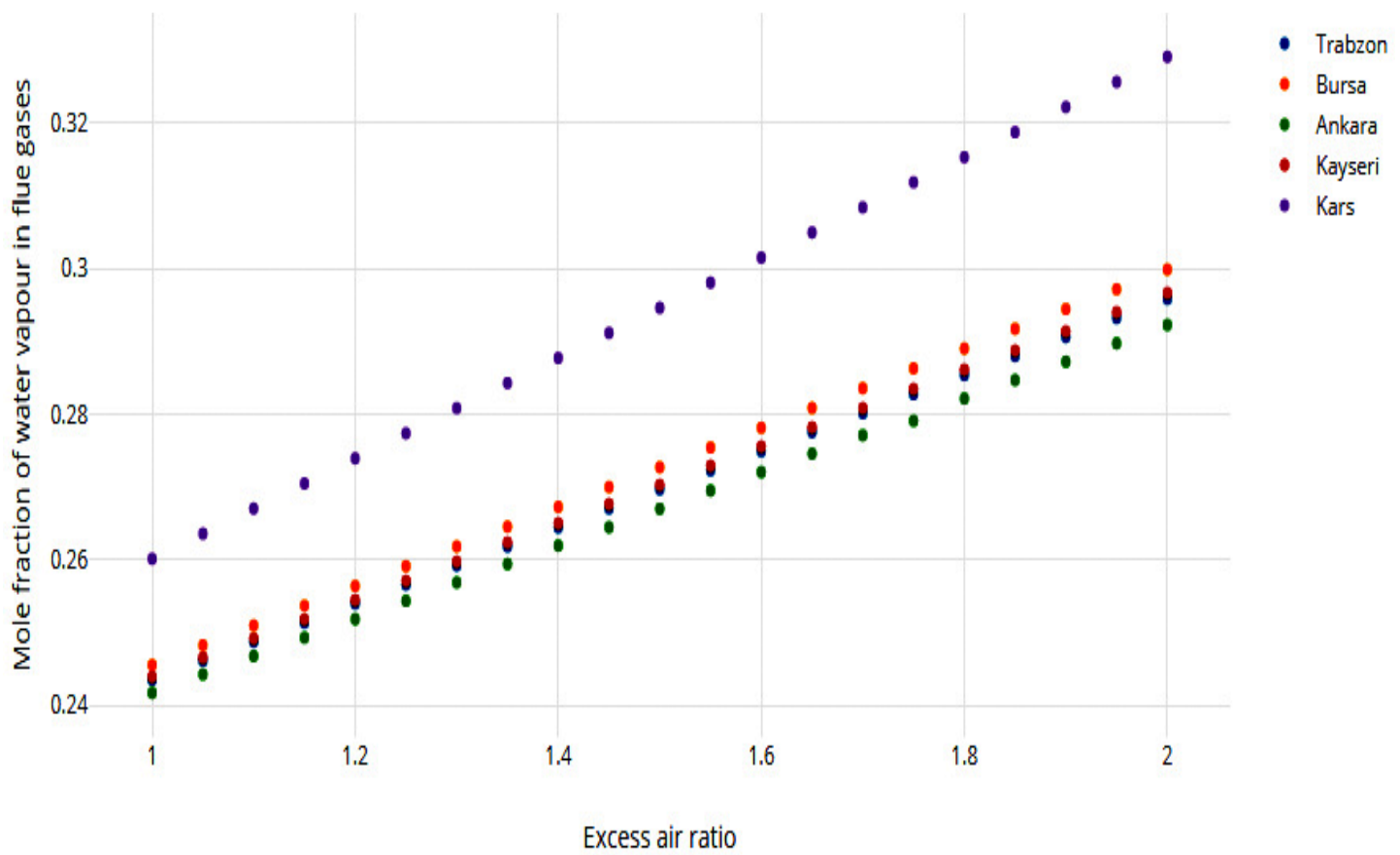

Figure 2. Changes of water vapour mole fraction with the excess air ratio

The mole fraction of water vapour in the flue gas has an important role to predict the dew point temperature of water vapour. The changes of the water vapour mole fraction in the flue gas with the excess air ratio are shown in Figure 2 for the five cities, called Trabzon, Bursa, Ankara, Kayseri and Kars in Turkey.

The dew point temperature of water vapour in flue gas changes with the excess air ratio and the altitude from sea level of the city. When the altitude is higher than sea level, the atmospheric pressure decreases. The lower atmospheric pressure is lead to the lower partial pressure and the dew point temperature of water vapour.

As shown in Figure 3, the dew point temperature of water vapour (DWT) is the highest for Trabzon city, has the altitude at the sea level. The DWT decreases depending on the increase of the excess air ratio. The acid dew point of the sulphuric acid (ADT) has the same effects, too (Figure 4).

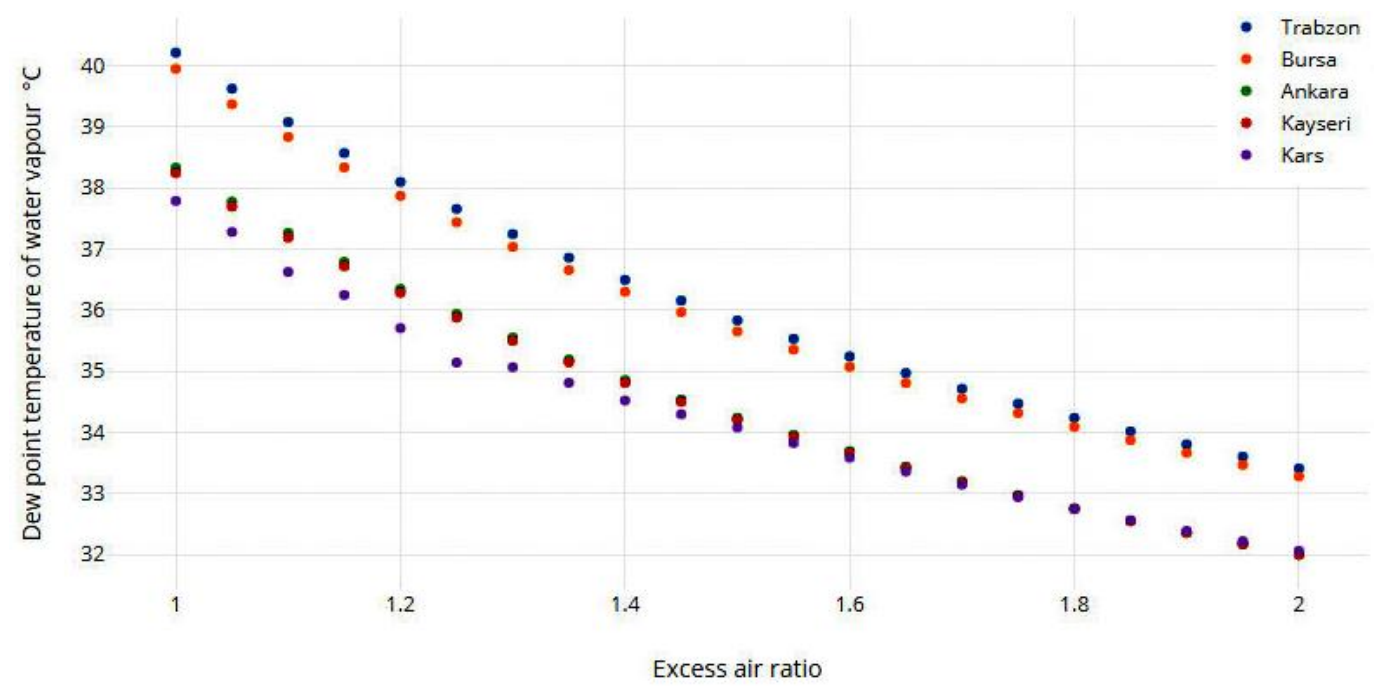

Figure 3. Changes of the DWT with the excess air ratio and the altitude of the city for the coal 
Journal of Thermal Engineering, Research Article, Vol. 7, No. 2, Special Issue 13, pp. 30-46, February, 2021

Table 3. The complete combustion results for Ankara

\begin{tabular}{|c|c|c|c|c|c|}
\hline$\lambda$ & $\mathrm{O}_{2} \%$ & $\mathrm{CO}_{2} \%$ & $\mathrm{H}_{2} \mathrm{O} \%$ & $\mathrm{~N}_{2} \%$ & $\mathrm{SO}_{2} \%$ \\
\hline 1 & 0.0 & 17.5906 & 7.1479 & 75.1912 & 0.0703 \\
\hline 1.05 & 0.9526 & 16.7805 & 6.8901 & 75.3099 & 0.0670 \\
\hline 1.1 & 1.8212 & 16.0417 & 6.6549 & 75.4181 & 0.0641 \\
\hline 1.15 & 2.6167 & 15.3652 & 6.4396 & 75.5172 & 0.0614 \\
\hline 1.2 & 3.3477 & 14.7434 & 6.2416 & 75.6083 & 0.0589 \\
\hline 1.25 & 4.0219 & 14.1701 & 6.0591 & 75.6923 & 0.0566 \\
\hline 1.3 & 4.6456 & 13.6396 & 5.8903 & 75.7700 & 0.0545 \\
\hline 1.35 & 5.2243 & 13.1474 & 5.7336 & 75.8422 & 0.0525 \\
\hline 1.4 & 5.7627 & 12.6895 & 5.5878 & 75.9092 & 0.0507 \\
\hline 1.45 & 6.2648 & 12.2625 & 5.4519 & 75.9718 & 0.0490 \\
\hline 1.50 & 6.7343 & 11.8632 & 5.3248 & 76.0303 & 0.0474 \\
\hline 1.55 & 7.1741 & 11.4891 & 5.2057 & 76.0851 & 0.0459 \\
\hline 1.6 & 7.5871 & 11.1379 & 5.0939 & 76.1366 & 0.0445 \\
\hline 1.65 & 7.9755 & 10.8076 & 4.9888 & 76.1850 & 0.0432 \\
\hline 1.7 & 8.3416 & 10.4962 & 4.8897 & 76.2306 & 0.0419 \\
\hline 1.75 & 8.6872 & 10.2023 & 4.7961 & 76.2736 & 0.0408 \\
\hline 1.8 & 9.0139 & 9.9244 & 4.7077 & 76.3144 & 0.0396 \\
\hline 1.85 & 9.3233 & 9.6613 & 4.6239 & 76.3529 & 0.0386 \\
\hline 1.9 & 9.6168 & 9.4117 & 4.5445 & 76.3895 & 0.0376 \\
\hline 1.95 & 9.8954 & 9.1747 & 4.4690 & 76.4242 & 0.0367 \\
\hline 2 & 10.1604 & 8.9494 & 4.3973 & 76.4572 & 0.0357 \\
\hline
\end{tabular}

According to the results, while the DWT changes in the range of $30-40{ }^{\circ} \mathrm{C}$, ADT varies between $140-125$ ${ }^{\circ} \mathrm{C}$. Thus, the predicting of the ADT is more important than DWT in the heat recovery applications for fuels, containing sulphur such as coal. When the flue gas temperature decreases down to the ADT, the $\mathrm{H}_{2} \mathrm{SO}_{4}$ vapour in the flue gas starts to the condensation.

The condensation liquid has a $\mathrm{pH}$ around 3 is very acidic and corrosive for the heat exchanger tube material. Due to these reasons, the more corrosion resistant tube material should use the latent heat exchanger or the flue gas temperature should not decrease down to the ADT. 
Journal of Thermal Engineering, Research Article, Vol. 7, No. 2, Special Issue 13, pp. 30-46, February, 2021

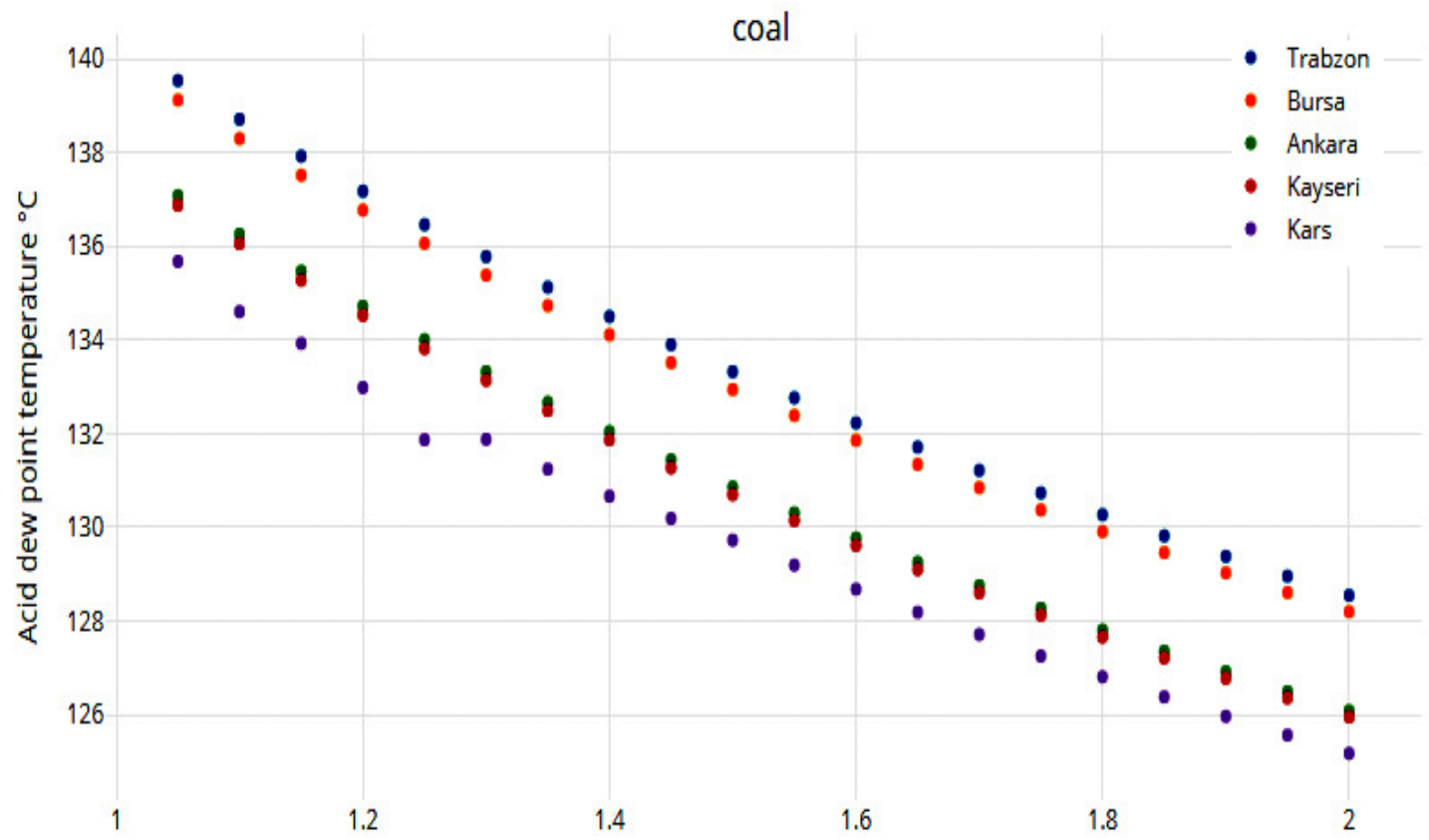

Excess air ratio

Figure 4. Changes of the ADT with the excess air ratio and the altitude of the city

Depending on the conversion rate, varies between the percent of 1-10 from $\mathrm{SO}_{2}$ to $\mathrm{SO}_{3}$ in the flue gas, the ADT increases. For the five cities, the changes with the content (ppm) of $\mathrm{SO}_{3}$ in the flue gas and the excess air ratio are shown respectively in Figure 5, Figure 6, Figure 7, Figure 8 and Figure 9.

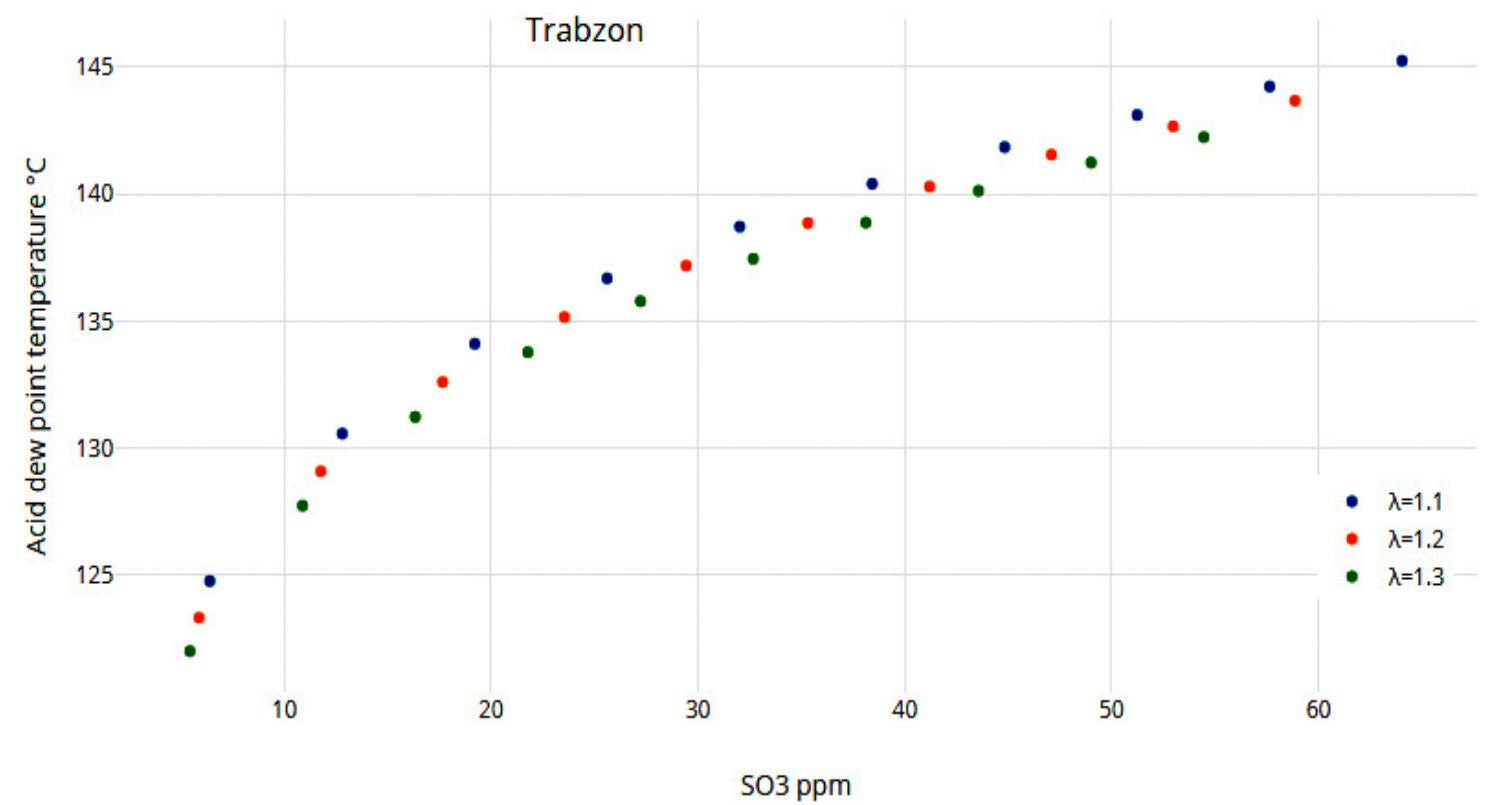

Figure 5. Change of the ADT according to the conversion rate for Trabzon city 
Journal of Thermal Engineering, Research Article, Vol. 7, No. 2, Special Issue 13, pp. 30-46, February, 2021

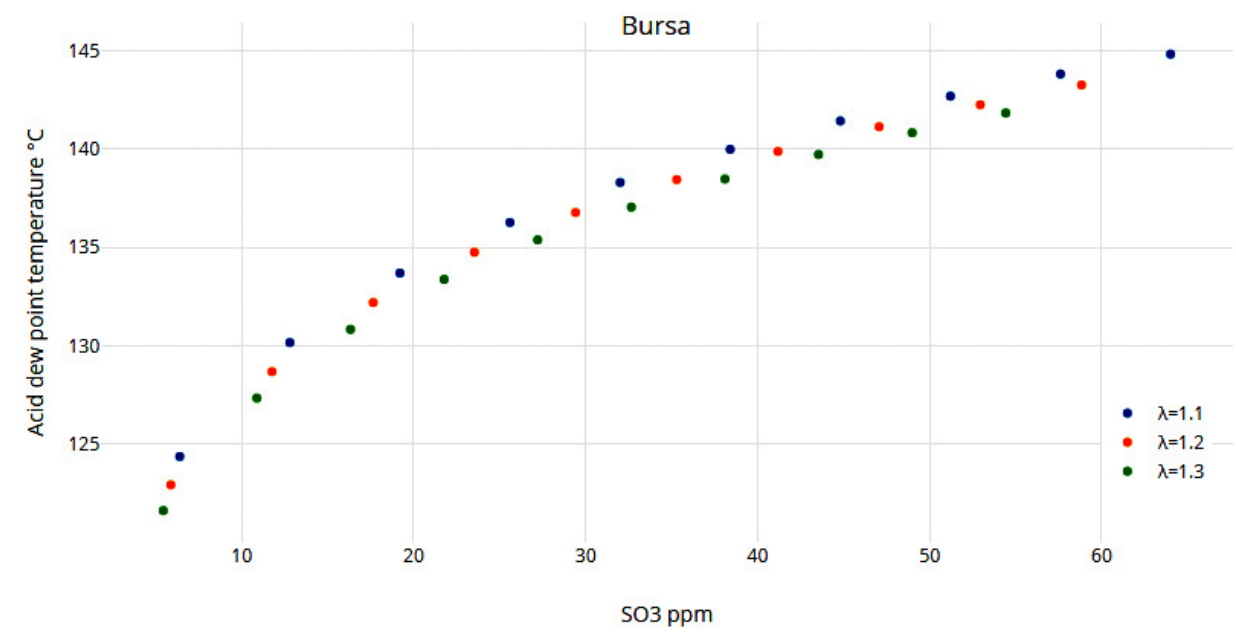

Figure 6. Change of the ADT according to the conversion rate for Bursa city

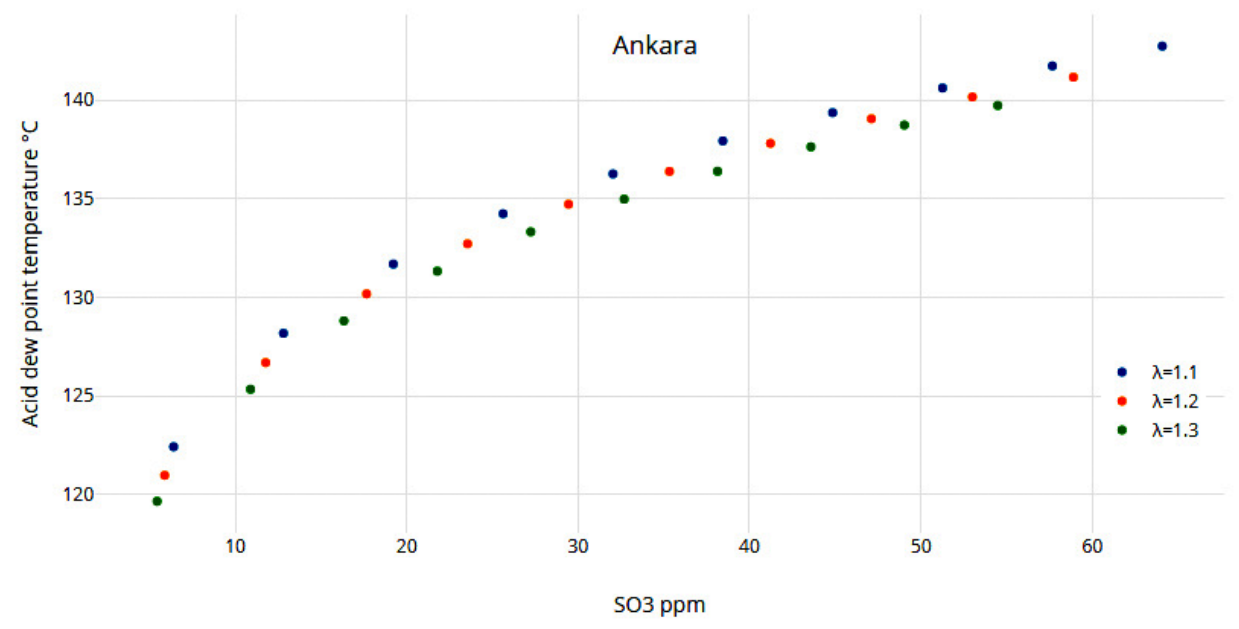

Figure 7. Change of the ADT according to the conversion rate for Ankara city

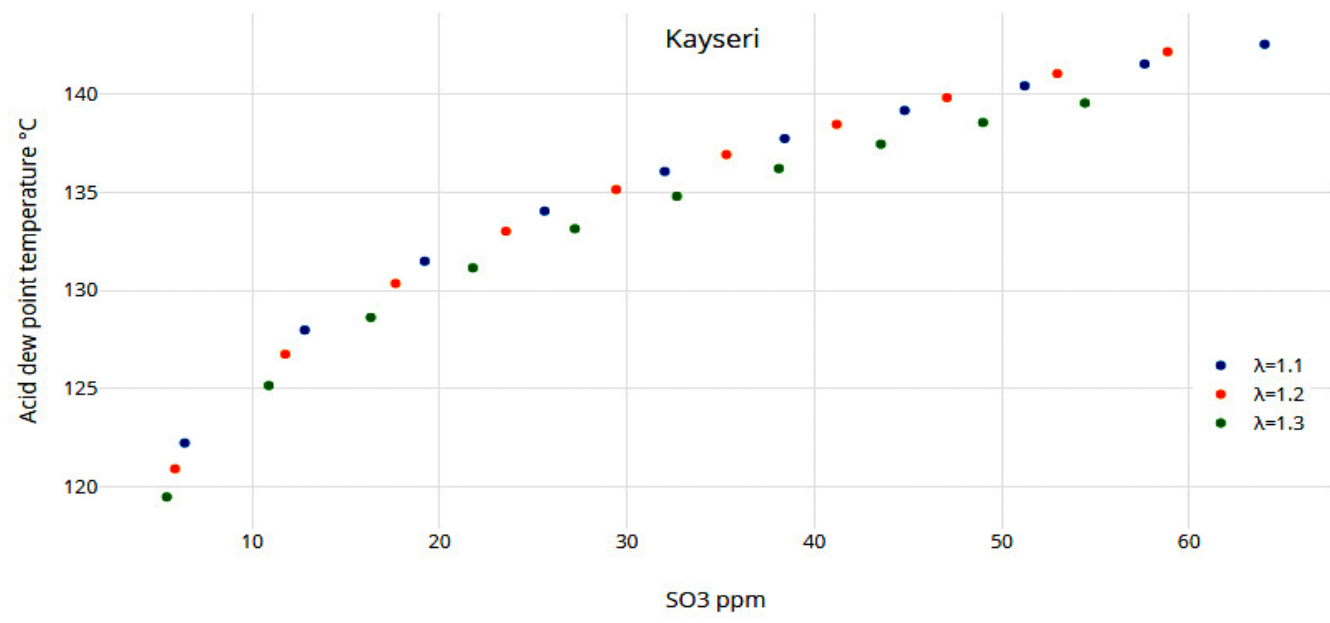

Figure 8. Change of the ADT according to the conversion rate for Kayseri city 
As a result of the study, the acid dew point temperature is shown how to change for the excess air ratio $\lambda=1.2$ in Table 4 . The ADT varies between $120-142{ }^{\circ} \mathrm{C}$ depending on the conversion rate of $\mathrm{SO}_{2}$ to $\mathrm{SO}_{3}$ for the city, called Kayseri. The ADT increases with the bigger conversion rate of the $\mathrm{SO}_{2}$ for the constant value of the excess air ratio.

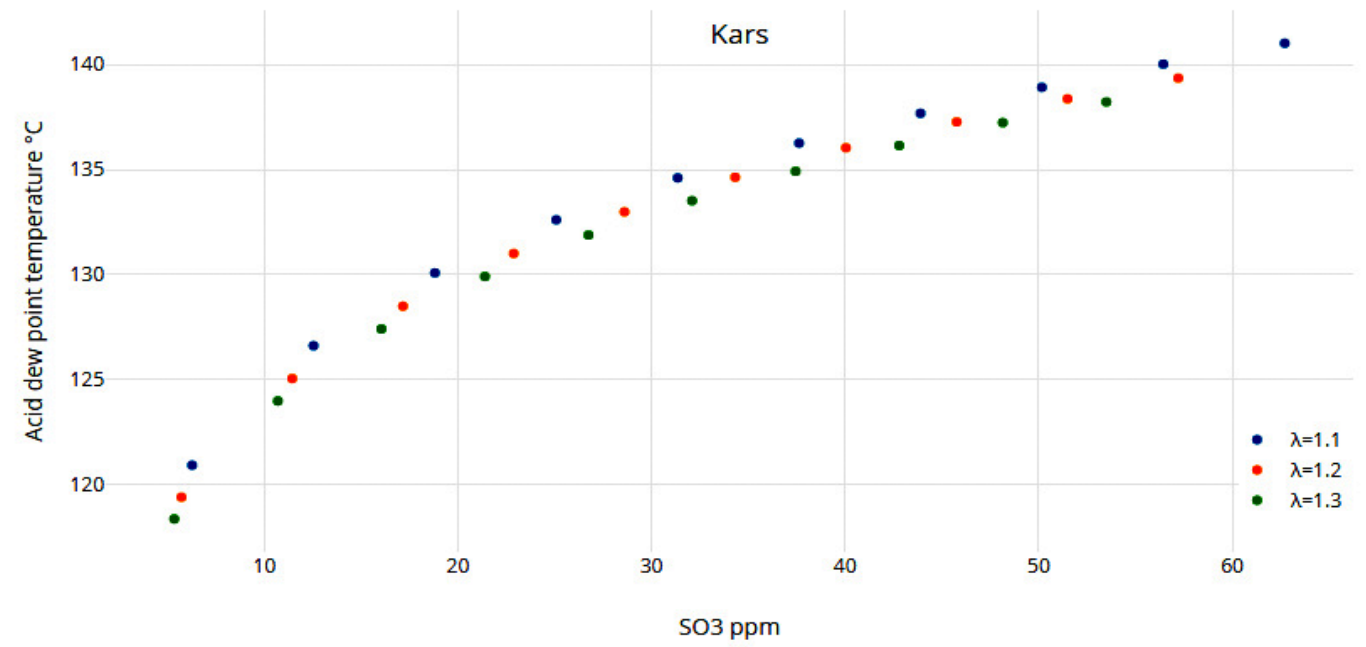

Figure 9. Change of the ADT according to the conversion rate for Kars city

In the combustion analysis of the wood, mass compositions, shown in Table 5 of the wood types were used [12]. The stoichiometric combustion reaction with dry air of the wood type, called hybrid poplar, is given in Eq. (23).

$$
\begin{aligned}
& C_{0.3097} \mathrm{H}_{0.4584} \mathrm{O}_{0.1872} \mathrm{~N}_{0.0029}\left(\mathrm{H}_{2} \mathrm{O}\right)_{0.0418}+1.13 \times 0.3306\left(\mathrm{O}_{2}+3.76 \mathrm{~N}_{2}\right) \\
& \quad \rightarrow 0.3097 \mathrm{CO}_{2}+0.2843 \mathrm{H}_{2} \mathrm{O}+1.2447 \mathrm{~N}_{2}
\end{aligned}
$$

\begin{tabular}{|c|c|c|c|}
\hline $\begin{array}{l}\mathrm{N}_{\mathrm{SO} 3} \\
\mathrm{ppm}\end{array}$ & $\begin{array}{l}\mathrm{N}_{\mathrm{H} 2 \mathrm{O}} \\
\mathrm{kmol}\end{array}$ & $\begin{array}{c}\mathrm{T}_{\mathrm{ADT}} \\
{ }^{\circ} \mathrm{C}\end{array}$ & $\lambda$ \\
\hline 5.89 & 0.2570 & 120.93 & \multirow{10}{*}{1.2} \\
\hline 11.77 & 0.2599 & 126.76 & \\
\hline 17.66 & 0.2623 & 130.36 & \\
\hline 23.54 & 0.2649 & 133.02 & \\
\hline 29.43 & 0.2676 & 135.14 & \\
\hline 35.31 & 0.2702 & 136.92 & \\
\hline 41.20 & 0.2729 & 138.45 & \\
\hline 47.09 & 0.2755 & 139.81 & \\
\hline 52.97 & 0.2781 & 141.03 & \\
\hline 58.86 & 0.2809 & 142.15 & \\
\hline
\end{tabular}

Table 4. Results of the ADT analysis for $\lambda=1.2$ and Kayseri city

The percent of the stoichiometric combustion products with dry air are shown in Figure 10 for the wood types in Turkey. For the city, Bursa has the percent of average relative humidity 70.34 in Turkey, the complete 
Journal of Thermal Engineering, Research Article, Vol. 7, No. 2, Special Issue 13, pp. 30-46, February, 2021

combustion reaction with moist air is given the Eq. (24) according to the wood type called willow tree. In the equation, the excess air ratio $(\lambda)$ is taken as 1.25 .

$$
\begin{aligned}
C_{0.3189} H_{0.4497} \mathrm{O}_{0.2008} \mathrm{~N}_{0.0029}\left(\mathrm{H}_{2} \mathrm{O}\right)_{0.0277}+1.25 \times 0.3309\left(\mathrm{O}_{2}+3.76 \mathrm{~N}_{2}+0.0266\left(\mathrm{H}_{2} \mathrm{O}\right)\right) \\
\rightarrow 0.3189 \mathrm{CO}_{2}+0.2858 \mathrm{H}_{2} \mathrm{O}+1.5566 \mathrm{~N}_{2}+0.0827 \mathrm{O}_{2}
\end{aligned}
$$

\section{stoichiometric combustion}

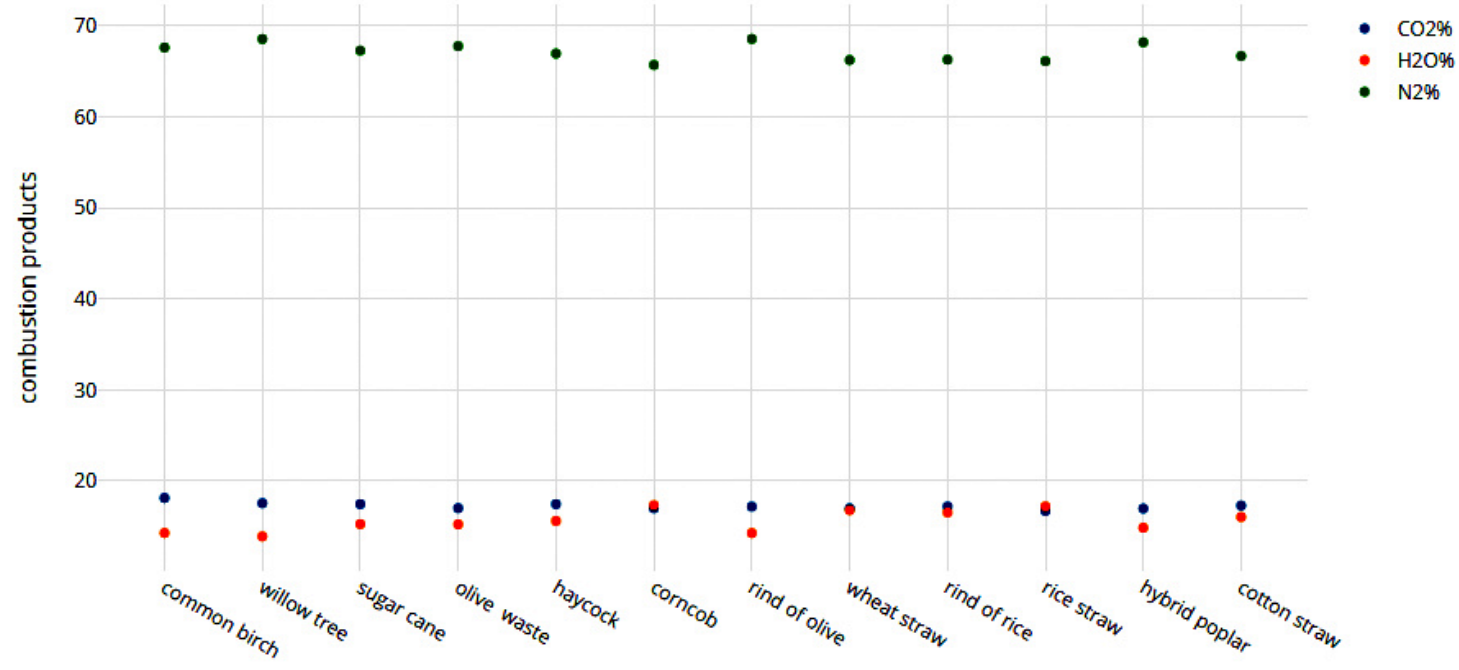

Figure 10. Percent of the stoichiometric combustion products with dry air for the wood types

To analyze the combustion with the moist air, calculating the mole number of water in the moist air needs. In the Figure 11, the mole number of the water in the air for the cities is indicated. As shown in Figure 11, depending on the relative humidity ratio of the cities the mole number of the water in the air changes.

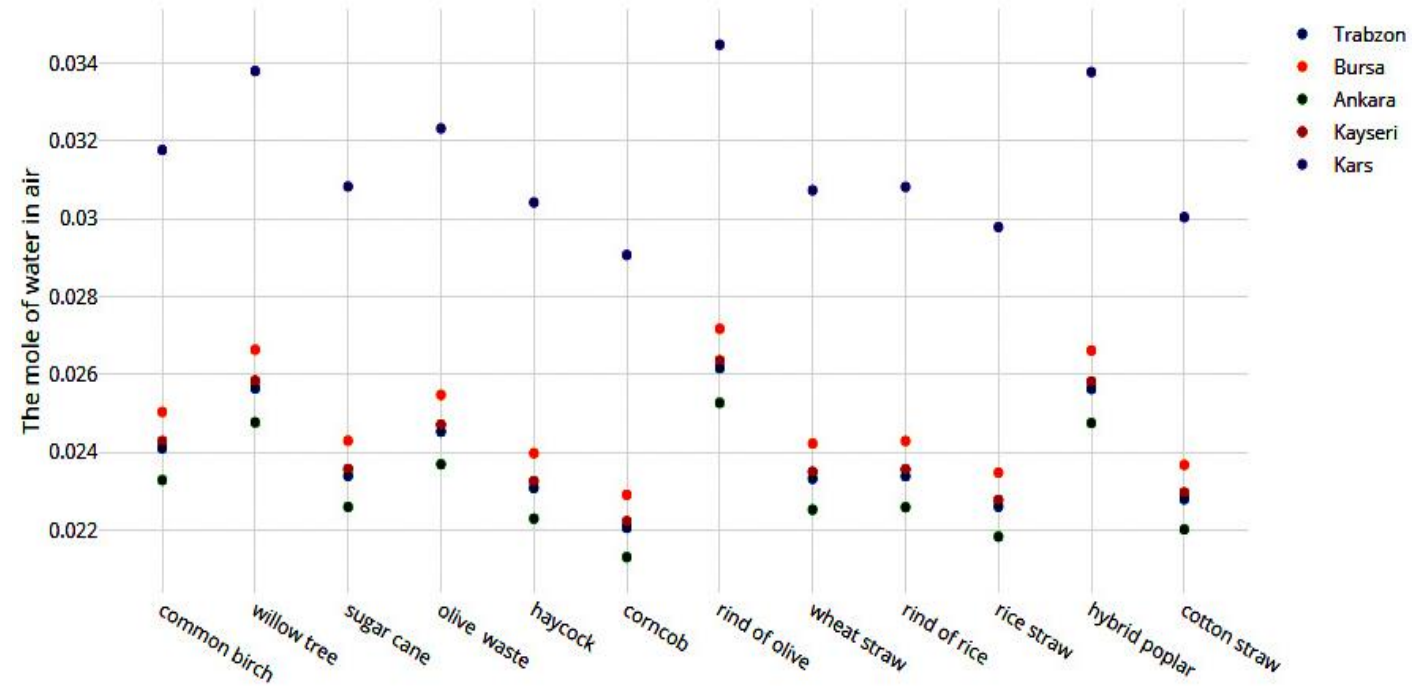

Figure 11. Mole number of water in the air for the cities 
The amount of water vapour in the flue gas increases with the moisture of the fuel and the combustion air. In the Figure 12, the percent of $\mathrm{H}_{2} \mathrm{O}$ in the flue gas is the lowest in the combustion with dry air, and the highest for the city, Kars because of the high relative humidity rate. Besides when the excess air ratio is increased, the percent of $\mathrm{H}_{2} \mathrm{O}$ rises, too. In the combustion corncob, type of wood, the percent of $\mathrm{H}_{2} \mathrm{O}$ is highest due to the moisture $(0.05509$ $\mathrm{kmol})$ of fuel content.

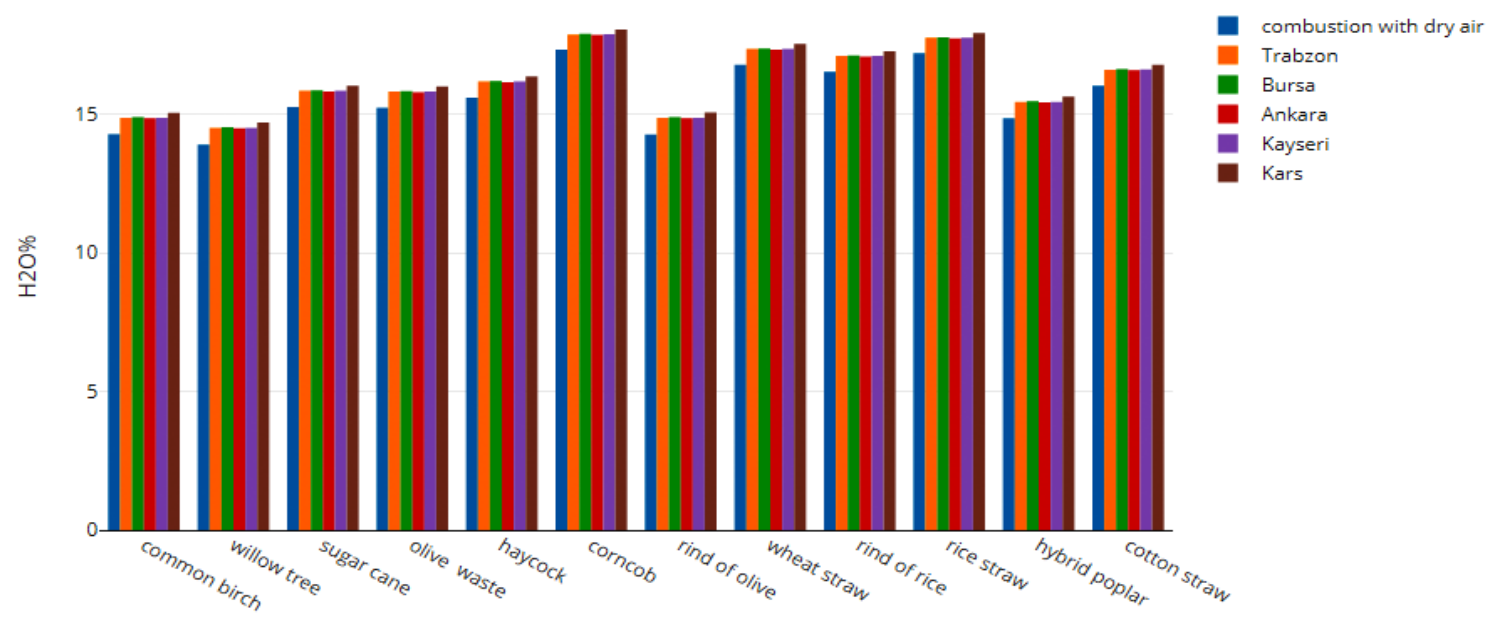

Figure 12. Percent of $\mathrm{H}_{2} \mathrm{O}$ in flue gas for the dry and moist air combustion

The dew point temperature changes between the range of $40-55{ }^{\circ} \mathrm{C}$ for the wood type, willow tree depending on the excess air ratio and the altitude from the sea level of the city. The change is shown in Figure 13. The DWT decreases by increasing the excess air ratio. The city, Trabzon has the highest DWT because of at the sea level. The results of the dew point temperature are given briefly according to the selected cities for solid fuels in Table 6. According to the results of the study, while the dew point temperature of the water vapour changes over the range $30-40{ }^{\circ} \mathrm{C}$ for the coal and $40-50{ }^{\circ} \mathrm{C}$ for the wood types, the acid dew point temperature waves to $125{ }^{\circ} \mathrm{C}$ from $140{ }^{\circ} \mathrm{C}$ for the coal types.

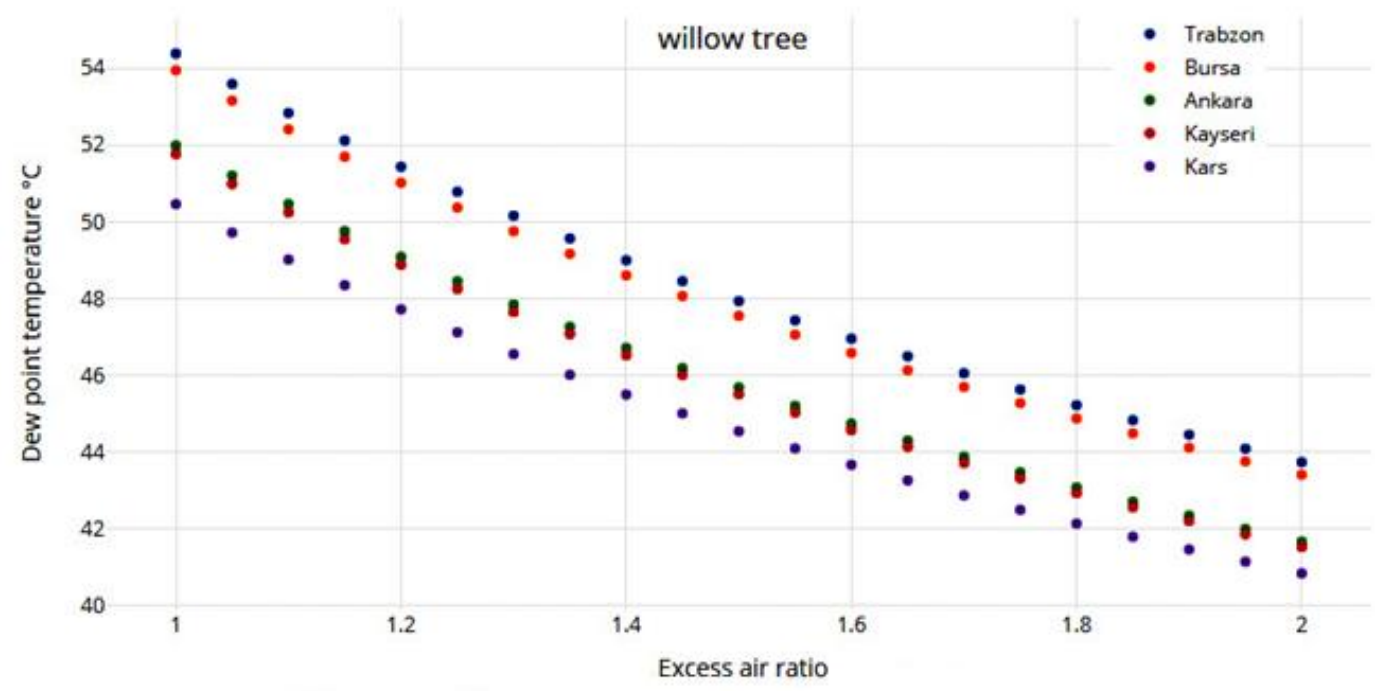

Figure 13. Changes of the DWT with the excess air ratio and the altitude of the city for the willow tree 
The results of this study are applied to an air preheater, design in Kars city in Turkey for a coal-fired boiler in a heating system. Required parameters for the design such as the outlet temperature of the flue gas from the boiler, the excess air ratio, the inlet temperature of combustion air to the boiler, the mass flows of the flue gas and the combustion air were taken from the heating system.

Table 6. Results of the dew point analysis for the fuel types and the cities

\begin{tabular}{|c|c|c|c|}
\hline & \multicolumn{2}{|c|}{$\mathrm{T}_{\mathrm{WDT}}{ }^{\circ} \mathrm{C}$} & $\mathrm{T}_{\mathrm{ADT}}{ }^{\circ} \mathrm{C}^{*}$ \\
\hline & Coal & Wood & Coal \\
\hline Trabzon & $40.21-33.41$ & $54.38-43.73$ & $139.54-128.54$ \\
\hline Bursa & $39.95-33.28$ & $53.94-43.41$ & $139.12-128.19$ \\
\hline Ankara & $38.33-31.99$ & $51.99-41.66$ & $137.08-126.08$ \\
\hline Kayseri & $38.24-31.98$ & $51.76-41.53$ & $136.88-125.95$ \\
\hline Kars & $37.78-32.06$ & $50.45-40.84$ & $135.67-125.17$ \\
\hline
\end{tabular}

Designed the air preheater consists of counter-cross flow, U-shaped stainless steel tube bundle. While cold air flows inside the tubes, flue gas flows from up to down on the horizontal tube bundles. In order to predict the condensing, the finite differences method is used and discrete the cells to one-dimensional during the tube flow. So that, the heat transfer rates, the flue gas and air inlet and outlet temperatures, surface temperatures of the tube wall, mole fractions of water vapour, sulphuric acid vapour and other non-condensing gases in the flue gas are calculated in each discrete cell. As the results of the design calculation, the air preheater consists of $25 \mathrm{~mm}$ external diameter and $1.2 \mathrm{~mm}$ thickness tube bundle.

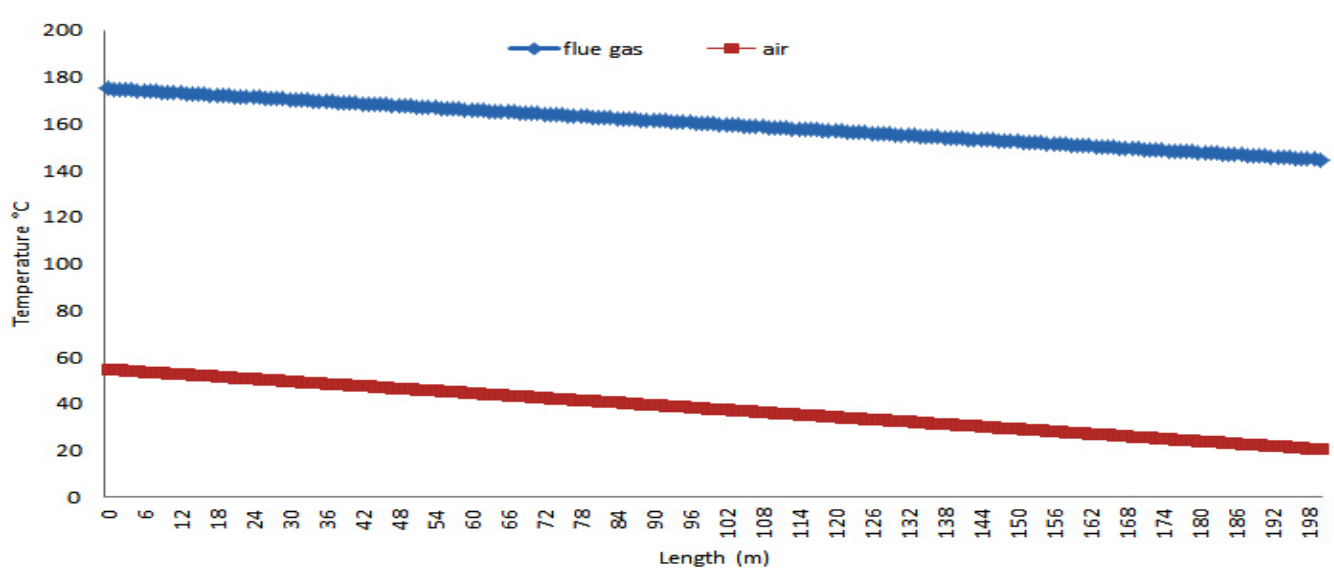

Figure 14. Changes of the flue gas and air temperature by the distance from the inlet air preheater 
Table 7. Design results of the heat exchanger

\begin{tabular}{|c|c|c|}
\hline \multicolumn{3}{|c|}{ Results and taken data from the heating system } \\
\hline Tube diameter & $\mathrm{mm}$ & 25 \\
\hline Total tube length & $\mathrm{m}$ & 200 \\
\hline Number of tubes & - & 204 \\
\hline Total heat surface area & $\mathrm{m}^{2}$ & 16.02 \\
\hline Air inlet temperature & ${ }^{\circ} \mathrm{C}$ & 20.81 \\
\hline Air outlet temperature & ${ }^{\circ} \mathrm{C}$ & 55 \\
\hline Flue gases inlet temperature & ${ }^{\circ} \mathrm{C}$ & 175 \\
\hline Flue gases outlet temperature & ${ }^{\circ} \mathrm{C}$ & 144.63 \\
\hline Air mass flow inside tubes & ${ }^{\mathrm{kg} / \mathrm{s}}$ & 1.94 \\
\hline Flue gases mass flow outside tubes & $\mathrm{kg} / \mathrm{s}$ & 2.03 \\
\hline Air velocity inside tubes & $\mathrm{m} / \mathrm{s}$ & 9.81 \\
\hline Flue gases velocity outside tubes & $\mathrm{m} / \mathrm{s}$ & 5.71 \\
& & \\
\hline
\end{tabular}

Tube material equipment is 316 quality stainless steel, $U$-shaped tube bundle is surrounded by stainless steel sheet metal, and $10 \mathrm{~cm}$ thickness stone wool of a side and metal on the other side equipment. It consists of 12 tubes on y-direction (width) and 17 tubes on z-direction (height), total in-line arrangement 204 tubes. The surface area of the air preheater is about $16.02 \mathrm{~m}^{2}$ and each tube length is $1 \mathrm{~m}$. Distances between the tubes are $\mathrm{S}_{\mathrm{y}}$ and $\mathrm{S}_{\mathrm{z}}$ equally $0.035 \mathrm{~m}$ in-line. A part of the heat exchanger design results and taken data from the heating system are shown in Table 7.

The calculation results by using finite difference method from the inlet heat exchanger tube to the outlet and changes of air and flue gas temperatures are shown in Figure 14. As seen in the figure, in the almost outlet of the air preheater the flue gas temperature is about $132.83^{\circ} \mathrm{C}$. Under these conditions; Kars city, coal mined from Zonguldak and the combustion 1.25 of excess air ratio with moist air; the acid dew point temperature is predicted as $131.87^{\circ} \mathrm{C}$. Under the temperature, the sulphuric acid vapour in the flue gas starts condensing. To conserve the tube material of the air pre-heater from the low-temperature corrosion the condensing of the sulphuric acid vapour does not wish because of the high corrosion effect. According to the design and analysis calculations, anywhere in the air preheater during tube flow, no dew point corrosion on the tube material can be observed because the flue gas temperature is high from the predicted ADT and DWT.

\section{CONCLUSION}

In this study, the combustion analysis is investigated for solid fuels such as various coal and wood types with moist air for different cities in Turkey. For the fuel types, the combustion effects are studied by using different excess air ratio. The dew point temperatures of water vapour (WDT) and sulphuric acid (ADT) are predicted as theoretical for various solid fuel types and the different cities in Turkey. The various factors such as the excess air ratio, relative humidity rate and the altitude of the city affected to the dew point temperatures and the concentration of the water and sulphuric acid vapour in flue gases are examined. In order to predict the condensing, an air preheater for the coal-fired boiler in the heating system is designed by using finite difference method. Designed the air preheater consists of the counter-cross flow $\mathrm{U}$-shaped stainless steel tube bundle. The tube is discredited 200 cells to one-dimensional during the flow. 
The heat transfer rates, flue gas and air inlet and outlet temperatures, the surface temperatures of the tube wall, the mole fractions of water vapour, sulphuric acid vapour and other non-condensing gases in the flue gas are calculated in each discrete cell. The results of the study are summarized as:

- According to the results, while the DWT changes in the range of $30-40{ }^{\circ} \mathrm{C}$, ADT varies between $140-125$ ${ }^{\circ} \mathrm{C}$ for the coal types in Turkey.

- The dew point temperature of water vapour (DWT) is the highest for Trabzon city, has an altitude at the sea level. The DWT decreases depending on the increase of the excess air ratio. The acid dew point of the sulphuric acid (ADT) has the same effects, too.

- The predicting of the ADT is more important than DWT in the heat recovery applications for fuels, containing sulphur such as coal.

- The dew point temperature changes between the range of $40-55{ }^{\circ} \mathrm{C}$ for the wood type, willow tree depending on the excess air ratio and the altitude from the sea level of the city.

- As the results of the design calculation, the air preheater consists of $25 \mathrm{~mm}$ external diameter and $1.2 \mathrm{~mm}$ thickness tube bundle. Tube material equipment is 316 quality stainless steel, $\mathrm{U}$-shaped tube bundle is surrounded by stainless steel sheet metal, and $10 \mathrm{~cm}$ thickness stone wool of a side and metal on the other side equipment. It consists of 12 tubes on y-direction (width) and 17 tubes on z-direction (height), total in-line arrangement 204 tubes.

- The surface area of the air preheater is about $16.02 \mathrm{~m}^{2}$ and each tube length is $1 \mathrm{~m}$. Distances between the tubes are $\mathrm{S}_{\mathrm{y}}$ and $\mathrm{S}_{\mathrm{z}}$ equally $0.035 \mathrm{~m}$ in-line.

\section{NOMENCLATURE}

$\begin{array}{ll}M_{A} & \text { Molecular mass, } \mathrm{kg} / \mathrm{kmol} \\ N & \text { Mole number, } \mathrm{kmol} \\ P & \text { Pressure, } \mathrm{kPa}, \mathrm{atm} \\ T & \text { Temperature, }{ }^{\circ} \mathrm{C}\end{array}$

Chemical symbols

$\begin{array}{ll}\mathrm{C} & \text { Carbon } \\ \mathrm{CO}_{2} & \text { Carbon dioxide } \\ \mathrm{H} & \text { Hydrogen } \\ \mathrm{H}_{2} \mathrm{O} & \text { Water } \\ \mathrm{H}_{2} \mathrm{SO}_{4} & \text { Sulphuric acid } \\ \mathrm{N}_{2} & \text { Nitrogen } \\ \mathrm{O}_{2} & \text { Oxygen } \\ \mathrm{SO}_{2} & \text { Sulphur dioxide } \\ \mathrm{SO}_{3} & \text { Sulphur trioxide }\end{array}$

Greek symbols

$\lambda$

Mole number of moisture in the air, kmol

$\phi \quad$ Relative humidity rate, $\%$

$\begin{array}{ll}\text { Subscripts } & \\ a & \text { Coefficient of stoichiometric combustion } \\ \text { air } & \text { Combustion air } \\ \text { ADP } & \text { Acid dew point } \\ \text { atm } & \text { Atmosphere } \\ f g & \text { Flue gases } \\ m & \text { Moisture } \\ \text { sat } & \text { Saturated } \\ W D P & \text { Water dew point }\end{array}$




\section{REFERENCES}

[1] Wei W, Sun F, Shi Y, Ma L. Theoretical prediction of acid dew point and safe operating temperature of heat exchangers for coal-fired power plants. Applied Thermal Engineering 2017;123:782-790. https://doi.org/10.1016/j.applthermaleng.2017.05.051.

[2] Xiang B, Tang B, Wu Y, Yang H, Zhang M, Lu J. Prediction acid dew point with a semi-empirical model. Applied Thermal Engineeing 2016;106:992-1001. https://doi.org/10.1016/j.applthermaleng.2016.06.040.

[3] Blanco JM, Pena F. Increase in the boiler's performance in terms of the acid dew point temperature: Environmental advantages of replacing fuels. Applied Thermal Engineering 2008;28:777-784. https://doi.org/10.1016/j.applthermaleng.2007.06.024.

[4] Pena F, Blanco JM. Evaluation of the physical dew point in the economizer of a combined cycle burning natural gas. Applied Thermal Engineering 2007;27:2153-2158. https://doi.org/10.1016/j.applthermaleng.2006.12.021.

[5] Ding Q, Tang XF, Yang ZG. Failure analysis on abnormal corrosion of economizer tubes in a waste heat boiler. Engineering Failure Analysis 2017;73:129-138. https://doi.org/10.1016/j.engfailanal.2016.12.011.

[6] Luo Y, Woolley E, Rahimiford S, Simeone A. Improving energy efficiency within manufacturing by recovering waste heat energy. Journal of Thermal Engineering 2015;1:337-344. https://doi.org/10.18186/jte.49943.

[7] Han H, He YL, Tao WQ. A numerical study of the deposition characteristics of sulfuric acid vapor on heat exchanger surfaces. Chemical Engineering Science 2013;101:620-630. https://doi.org/10.1016/j.ces.2013. 07.024

[8] Vainio E, Kinnunen H, Lauren T, Brink A, Yrjas P, DeMartini N, Hupa M. Low-temperature corrosion in cocombustion of biomass and solid recovered fuels. Fuel 2016; 184:957-965. https://doi.org/10.1016/j.fuel. 2016.03.096.

[9] ZareNezhad B, Aminian A. Accurate prediction of the dew points of acidic combustion gases by using an artificial neural network model. Energy Conversion and Management 2011;52:911-916. https://doi.org/10.1016/j.enconman.2010.08.018.

[10] Li X, Wu Z, Zhang L, Liu X, Zhu X, Hu H, Luo G, Hu Z, Liu W, Yao H. An updated acid dew point temperature estimation method for air-firing and oxy-fuel combustion processes. Fuel Processing Technology 2016;154:204-209. https://doi.org/10.1016/j.fuproc.2016.08.033.

[11] Shi Y, Dai C, Ma Z, Guo Z. Experimental investigation of heat transfer with ash deposition in ultra-low temperature WHRS of coal-fired power plant. Applied Thermal Engineering 2017;123:1181-1189. https://doi.org/10.1016/j.applthermaleng.2017.05.190.

[12] Cengel YA, Boles MA. Thermodynamics an engineering approach. Guven Scientific Press; 2008.

[13] Bilgen S. Bazı yakıtların kimyasal ekserji değerlerinin hesaplanması. Yüksek Lisans Tezi 2000. Karadeniz Teknik Üniversitesi, Trabzon, Türkiye. 